\title{
Effects of Piliostigma reticulatum on the Vegetation Dynamic in Sudanian Zone of Burkina Faso
}

\author{
Barthélémy Yélémou ${ }^{1}$, Abdoulaye Tyano ${ }^{2}$, Babou André Bationo ${ }^{3}$, Bassiaka Ouattara ${ }^{4}$, Jonas Koala ${ }^{5}$ \& Jeanne \\ Millogo Rasolodimby ${ }^{6}$ \\ ${ }^{1}$ Institut de 1'Environnement et de Recherches Agricoles (INERA)-Saria, Département Gestion des Ressources \\ Naturelles et Systèmes de Production (GRN/SP), BP 10 Koudougou, Burkina Faso \\ ${ }^{2}$ Centre Universitaire Polytechnique de Dédougou (CUPD), Université Ouaga I, Pr Joseph Ky Zerbo, \\ Ouagadougou, 03 BP 7021 Ouagadougou 03, Burkina Faso \\ ${ }^{3}$ Institut de l'Environnement et de Recherches Agricoles (INERA), Département Environnement et Forêts (DEF), \\ 01 BP 476 Ouagadougou 01, Burkina Faso \\ ${ }^{4}$ Centre Universitaire Polytechnique de Fada N'Gourma, Université de Ouagadougou, 03 BP 7021 Ouagadougou \\ 03, Burkina Faso \\ ${ }^{5}$ Institut de l'Environnement et de Recherches Agricoles (INERA)-Saria, Département Environnement et Forêts \\ (DEF), BP 10 Koudougou, Burkina Faso \\ ${ }^{6}$ Université Ouaga I, Pr Joseph Ky Zerbo, 03 BP 7021 Ouagadougou 03, Burkina Faso \\ Correspondence: Barthélémy Yélémou, Institut de l'Environnement et de Recherches Agricoles (INERA)-Saria, \\ Département Gestion des Ressources Naturelles et Systèmes de Production (GRN/SP), BP 10 Koudougou, \\ Burkina Faso. Tel: 226-7052-9060. E-mail: yelbart@ hotmail.com
}

Received: March 23, 2017

doi:10.5539/jps.v6n2p77
Accepted: June 23, 2017 Online Published: July 20, 2017

URL: https://doi.org/10.5539/jps.v6n2p77

\begin{abstract}
This study aims at identifying the effect of $P$. reticulatum on the vegetation regeneration dynamic in Sudanian fallows of Burkina Faso. Two fallows of about twenty years old have been considered. The point quadrat method was used for herbaceous inventory. Aboveground biomass has been estimated. Moreover, effect of $P$. reticulatum on the regeneration of others woody species has been studied under, at the limit and out of the shrub canopy. In north Sudanian zone, inventory recorded 39 herbaceous species of which 23 species under the canopy and 16 in open grassland, distributed in 12 families and 22 genera. In south Sudanian zone, species diversity is 41 species from which 23 under the canopy and 18 out of, spread in 16 families and 26 genera. Species higher than $80 \mathrm{~cm}$ have been observed only under $P$. reticulatum canopy in south and north Sudanian zone. In addition, no species of striga met in open sunlight has been observed under the shrub canopy. East and West directions recorded the important proportions of species with individuals belonging to the stratum superior to $100 \mathrm{~cm}(3.13$ and $4.81 \%$ in north direction, 1.47 and $1.73 \%$ in south directions).
\end{abstract}

Keywords: Piliostigma reticulatum, dynamic, trees, herbaceous, Burkina Faso

\section{Introduction}

Piliostigma reticulatum is protected from cuts for decades in agricultural landscape of the central plateau of Burkina Faso (Yélémou, Bationo, Yaméogo, \& Millogo-Rasolodimby, 2007). At the beginning of the rainy season, its leaves are frequently cut to serve as mulch in the crusty area in the fields (Yélémou et al., 2007) while the pods are harvested by shepherds to feed cattle at the end of rainy season. P. reticulatum is subjected to an increasing anthropization due to its high presence in the agricultural landscape in Sahelo-Sudanian zone of Burkina Faso.

During these last years with regression of traditional agroforestry species due to climatic risks, excessive exploitation, and their low ability to regenerate, $P$. reticulatum is more and more adopted by the populations of the central plateau as agroforestry species (Yélémou et al., 2007). Competition relationship between trees and herbaceous has been often reported in functioning models and management of savanna (Akpo \& Grouzis, 2009). Several authors showed that in semi-arid areas, tree promote not only climatic factors but increase also diversity 
of woody regeneration and the diversity and the production of herbaceous stratum (Apko, Banoin \& Grouzis, 2003; Akpo \& Grouzis, 2009; Diallo et al., 2015). Nevertheless, the effect of tree on the herbaceous dynamic and woody regeneration could depend on the rainfall characteristic of the study site. For Yélémou, Yameogo, Bationo, Millogo/Rasolodimby et Hien, (2008), P. reticulatum, due to its bushy nature and its abundant leave biomass, contributes to reduce water and wind erosion and promotes vegetation regeneration. P. reticulatum should be of great importance in the sustainable management policy of soils in the Sahelo-sudanian zones through a better understanding of its function in the mechanism of environmental regeneration.

This study, conducted in two Sudanian ecosystem of Burkina Faso (north Sudanian and south Sudanian), has for goal to determine on one hand, the influence of tree on species structure of the herbaceous layer and the above ground phytomass production, and on the other hand on the state of woody regeneration.

\section{Material and Methods}

\subsection{Study Sites}

The study is carried out both at the research station of INERA in Saria, located in north Sudanian zone and at Sala in south Sudanian climatic zone in Burkina Faso (Figure 1)

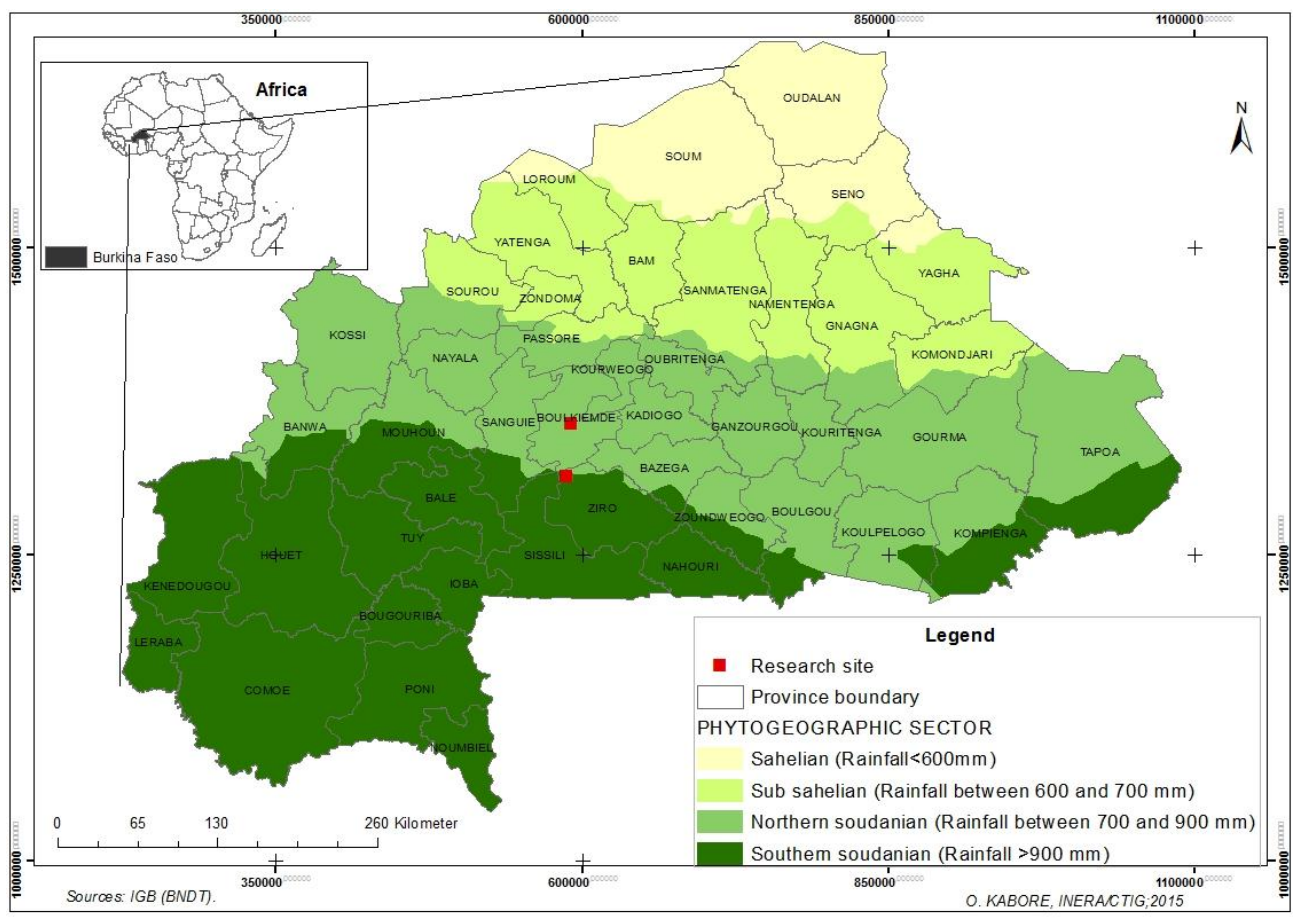

Figure 1. Site location map

North Sudanian zone is characterized by a long dry season from October to April (7 months) and a short rainy season from May to September (5 months). Harmattan wind is cold and dry and blows during the dry season and the monsoon is the dominant wind during the rainy season. Annual rainfall in the past decade ranged between 626.4 and $980.7 \mathrm{~mm}$ with an average of $852.03 \mathrm{~mm}$ in Saria.

South Sudanian part is characterized by a dry season from November to April (6 months) and a rainy season from May to October (six (6) months). The prevailing wind in rainy season is the continental trade wind.

The temperature is about $35.8^{\circ} \mathrm{C}$ at Saria and $28^{\circ} \mathrm{C}$ at Sala (Yélémou et al., 2007). In Saria, maximum temperature $\left(40{ }^{\circ} \mathrm{C}\right)$ is reached in March-April and the minimum $\left(15^{\circ} \mathrm{C}\right)$ in December. In the south Sudanian zone, The thermal amplitudes in south Sudanian zone is relatively lower than the one of north Sudanian due mostly to vegetation cover which forms a buffer system on the climate, reducing temperature

The site in Saria is a protected fallow with monospecific vegetation of $P$. reticulatum, while in Sala site it is an open fallow, with multispecies vegetation. The two fallows are over 20 years old. Vegetation in south Sudanian zone is characterized by Isoberlinia doka Craib \& Stapf, which forms tree stands in woodlands of Burkina Faso. Savanna woodlands in Sala are dominated by Detarium microcarpum Guill.\&Perr., Combretum glutinosum Guill. \& Perr., Gardenia erubecens Stapf. \& Hucth. et Parina ricuratellifolia. The graminaceae stratum is dominated 
by Andropogon gayanus Kunth, Andropogon ascinodis C.B.Clarke in old fallows, Eragrostis tremula Hochst. Penissetum pedicellutum Trin, Dactyloctenium aegyptium, Andropogon pseudapricus Stapf., Loudetia togoensis (Pilg.) C.E.Hubb., in recent fallow.

\subsection{Floristic Inventory of Herbaceous Stratum}

The floristic inventory of the herbaceous stratum was achieved using the method of quadrat point of Godron et al., (1969). This method is recognized for its accuracy, easness use and its non-destructive nature of natural environment.

In practice, it consisted to check off all the herbaceous species at the vertical of regular points (each $20 \mathrm{~cm}$ ) along of a graduate twine of $20 \mathrm{~m}$ long above the grass layer. Then, for each line, we have 100 lecture points. Several species can be counted by lecture point, but by convention, each species has been counted only one time. Then, this alows to characterize the importance of each species in the vegetation layer measuring its cover by the obervation of frequencies (floristic analysis). Herbaceous inventory has been conducted on four lines in each site from which two lines crossed at least two $P$. reticulatum canopy and the others two lines didn't cross any $P$. reticulatum crown. The lines were randomly spread following the prescription of Boudet (1984). Then, for each site we had a sample of 400 lecture points. The number of lecture points is important for the accuracy of the results, then the exactness of the sampling is obtained by the calculation of the confidence interval (I.C) of which $5 \%$ value allows to eliminate random effect (Boudet,1984).

$$
\text { I.C }= \pm \sqrt{\frac{n(N-n)}{N^{3}}}
$$

$\mathrm{N}=$ cumulative number of contacts of all the species

$\mathrm{n}=$ cumulative number of contacts of the dominant species.

The inventories were achieved at the beginning of October. This period corresponds to active vegetation, heading-fructing of dominant species and when the species are most discernible (Sawadogo, 2009).

\subsubsection{Study of the Vertical Structure of Herbaceous Cover}

Vertical structure allows to visualize the differents stand layers. Study of the stratification of herbaceous cover was achieved through plot method. So, 9 square plots of $1 \mathrm{~m}^{2}$ each were designed under each shrub of $P$ reticulatum (Fig 2). Plots were replicated 4 times and were designed as follow:

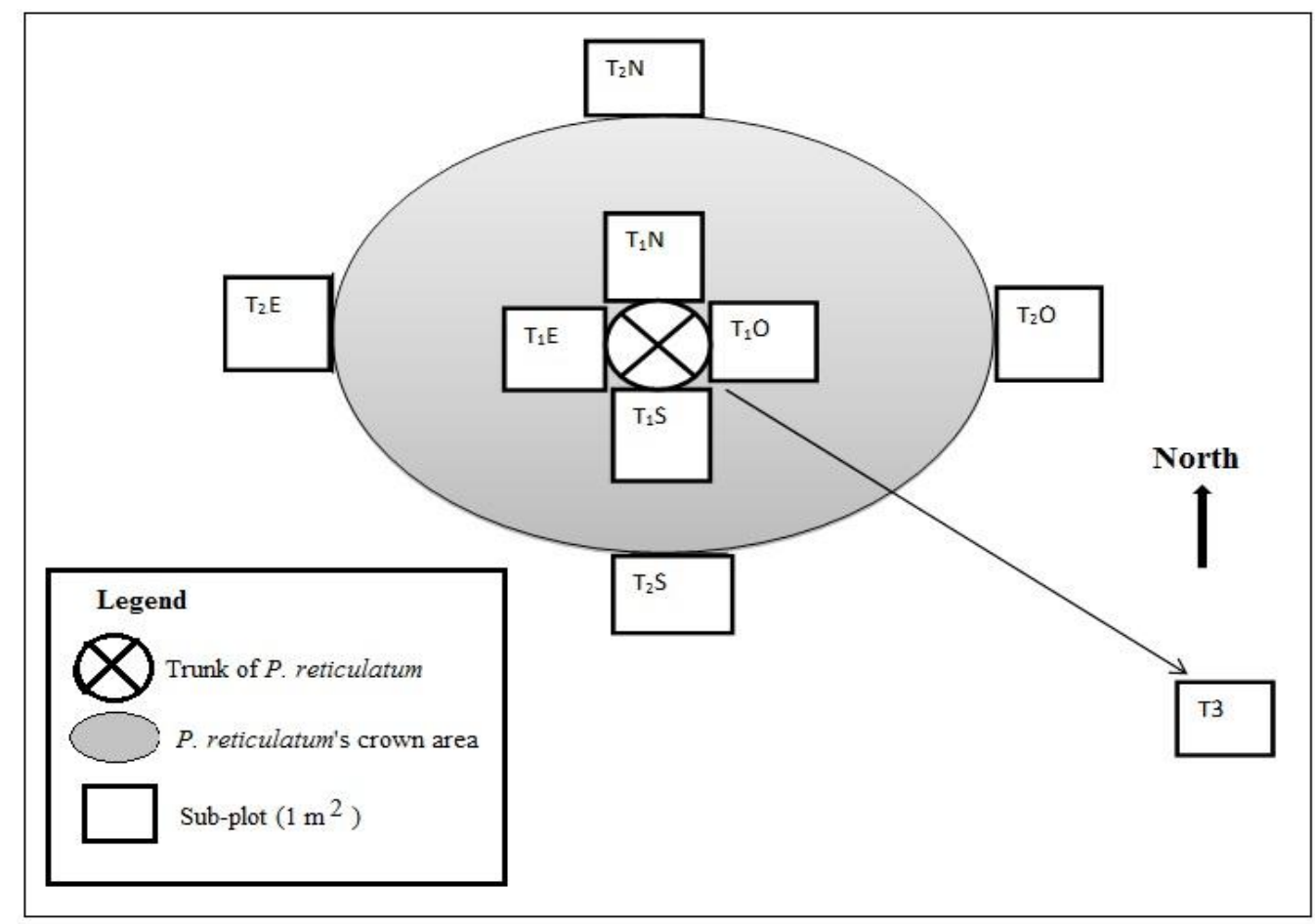

Figure 2. Experimental design for the study of vertical structure of herbaceous 
$\mathbf{P}_{\mathbf{1}}$ E: under $P$. reticulatum shrub, East side, $\mathbf{P}_{\mathbf{1}} \mathbf{O}$ : under $P$. reticulatum shrub, West side, $\mathbf{P}_{\mathbf{1}} \mathbf{N}$ : under $P$. reticulatum shrub, North side, $\mathbf{P}_{1} \mathbf{S}$ : under $P$. reticulatum shrub, South side, $\mathbf{P}_{2} \mathbf{E}$ : at the limit of the crown of $P$. reticulatum, East side, $\mathbf{P}_{2} \mathbf{O}$ : at the limit of the crown of $P$. reticulatum, West side, $\mathbf{P}_{2} \mathbf{N}$ : at the limit of the crown of $P$. reticulatum, North side, $\mathbf{P}_{2} \mathbf{S}$ : at the limit of the crown of $P$. reticulatum, South side, $\mathbf{P}_{3}$ : out of the crown of $P$. reticulatum

$\mathrm{P}_{1}$, under $P$. reticulatum shrub; the plot $\mathrm{P}_{1}$ has 4 variantes that are $\mathrm{P}_{1} \mathrm{E}, \mathrm{P}_{1} \mathrm{O}, \mathrm{P}_{1} \mathrm{~N}$ and $\mathrm{P}_{1} \mathrm{~S}$ (for the four cardinal directions East, West, North and South respectively);

$\mathrm{P}_{2}$, at the limit of the canopy of $P$. reticulatum shrub; the plot $\mathrm{P}_{2}$ has also 4 variantes $\mathrm{P}_{2} \mathrm{E}, \mathrm{P}_{2} \mathrm{O}, \mathrm{P} 2 \mathrm{~N}$ and $\mathrm{P}_{2} \mathrm{~S}$ (for the four cardinal directions East, West, North and South respectively)

P3, out of the crown of $P$. reticulatum shrub, in open sunligth

In each plot, herbaceous species were recorded according to the following stratums : 0-20 cm, 20-40 cm, 40-60 $\mathrm{cm}, 60-80 \mathrm{~cm}, 80-100 \mathrm{~cm}$ and $>100 \mathrm{~cm}$

\subsubsection{Assement of the Aboveground Phytomass}

The assesment of herbaceous biomass was achieved through complete harvest method (Ouédraogo, 2003). Herbaceous in the square plots of $1 \mathrm{~m}^{2}$ have been cut, and a manual screening allows to separate the different herbaceous species.

Each species sample was immediatly weighted using an electronic scale (Mettler PM 4000, $d=0,01, e=0,1$ ) in order to determine its contribution to the herbaceous biomass in the corresponding pot. Samples were packed in biodegradable plastic bag and labeled. Then, sample were sun dry and afterward oven dry until constant dry weight and values of dry matter have been determined.

The quantities of dry phytobiomass were afterward gathered into three forage types according to the following biological forms:

-the annual graminaceae $(\mathrm{Ga})$ perennial graminaceae $(\mathrm{Gv})$ : they constitute the most abundant forage type in tropical regions (Daget \& Godron, 1995);

- the leguminous (Le) : they are characterised by their ability to fixe atmospheric nitrogen and so by a great nitrogen content;

- and at last the others species ( $\mathrm{Au}$ ) or forbs

The assesment of phytobiomass was achieved at first October and in the same plots that allow studying the vertical herbaceous structure. This period corresponds to the phenological stage of maximal production of biomass. Likewise, forage are mown at this period. A total of 36 plots have been installed in each site according to Boudet (1984) who recommands a minimum of 20 plots to obtain an accuracy of 5\%.

Study of woody regeneration

The inventories of woody regeneration have concerned four (04) P. reticulatum shrub. For each shrub, nine ( 09) square plots of $1 \mathrm{~m}^{2}$ were designed as the plots used for the study of vertical structure of herbaceous (fig 2). In these plots, all the woody species in regeneration have been recorded. Dendrometric variables like total height, collar diameter, diameter of the great crown and diameter of the small crown have been recorded. Measures of height have been achieved using a pole as well as measure of great crown and small crown. The collar diameter was recorded with a vernier calliper.

Statistical analysis

The following variables, characteristic of the vegetation, defined by Daget and Poissonnet (1971) have been determined.

The species richness (S) that represents the number of species met in a given area.

The species frequence of species $\mathrm{i}(\mathrm{FSi}$ ) that corresponds to the ratio of the number of points where species I has been recorded (Boudet, 1984) to the total number of points.

The centesimal frequence of the species $\mathrm{i}(\mathrm{FCi})$ that corresponds to the ratio in percentage of the species $\mathrm{i}$ frequence and the number of point $(\mathrm{N})$ sampled. It expresses the species cover corresponding to proportion of soil surface covered by a vertical projection of aboveground organs of this species:

$$
\mathbf{F C}_{\mathbf{i}}=\frac{F S i}{N} X 100
$$


The specific contribution of the species $\mathrm{i}\left(\mathrm{CS}_{\mathrm{i}}\right)$ is defined as the ratio of FCi to the sum of FCi of all the species recorded. It expresses the contribution of the species to the aboveground congestion.

The formula is:

$$
\mathrm{CS}_{\mathrm{i}}=\frac{F C i}{\Sigma F C i}
$$

A species is considered as productive if its specific contribution is higher than 5\% (Sawadogo, 1996). These species contribute significantly to the global recovery of the vegetation and to the phytomass production.

Variables of species diversity have been computed as:

- Shannon diversity index $(\mathrm{H})$, Piélou equitability index $(\mathrm{E})$ : it represents the expression of the balance in the repartition of individuals among species. Its value tends to 0 when there is a predominance phenomenon and to 1 when all the species have almost the same trend.

$$
H=-\sum_{i=1}^{N} p i . \operatorname{lnpi} \quad H \max =\ln N \quad E=\frac{H}{H \max }
$$

$\mathrm{pi}=$ relative proportion of the species (i), $\mathrm{N}=$ number of species, $\ln =$ Neperian Logarithm

In the order to appreciate the stability of the herbaceous grouping, "J" curve of Raunkaier (Savadogo, 2007) have been represented. This curve informs on the stability of the flora. The knowledge of the number of species and their frequencies allow establishing this curve by grouping the species in the five classes of frequencies as below:

$\mathrm{A}=0-20 \%, \mathrm{~B}=21-40 \%, \mathrm{C}=41-60 \%, \mathrm{D}=61-80 \%, \mathrm{E}=81-100 \%$. The grouping is said:

stable if $\mathrm{A}>\mathrm{B}>\mathrm{C} \geq \leq \mathrm{D}<\mathrm{E}$, this corresponds to a unimodal curve ;

disturbed if this equality isn't respected, the curve is bimodal or plurimodal.

In addition, data of herbaceous biomass have been subjected to a one-way ANOVA using the test of least squares of Fischer (LSD) in order to compare the means of the different variables under and out of the crown of $P$. reticulatum at 5\% level. The statistical analysis have been achieved using XLSAT sotfware, 2007 edition.

\section{Results}

\subsection{Characteristic of Grass Layer of P. Reticulatum Formations}

\subsubsection{Floristic Composition}

In the north Sudanian zone, 39 herbaceous species belonging to 12 families and 22 genera were inventoried. The family of graminaceae with 14 species corresponding to $35 \%$ of the species is the most represented followed by Fabaceae family (15\%), Cesalpiniaceae family and Acanthaceae family each $7.5 \%$. The less represented families are Polygalaceae, Scrofulariaceae and Sterculiaceae, each family with $2.5 \%$ of inventoried species.

Under $P$. reticulatum crowns, 23 herbaceous species belonging to 19 families have been identified whereas 16 species belonging to 9 families have been identified out of the crown, at open grassland. The family of graminaceae is most dominant under and out of the crown of $P$. reticulatum where its represents $33.33 \%$ and $37.5 \%$ recovery rate respectively. However, it is recorded that Papilionaceae family represented under the crown of $P$. reticulatum by Alysicarpus ovalifolius (Schum Et Thon.), and Indigofera Suffructicosa Mill., is absent out of the crown. On the contrary, the family of Scropheulariaceae represented out of the crown by Striga hermontica (Del.) Benth., is absent under the crown of $P$. reticulatum.

A total of 41 grass species belonging to 16 families and 26 genera have been inventoried in the south Sudanian zone. In this zone, it is also the family of graminaceae that is dominant with $36.58 \%$ of the species. Afterward, follow families of Acanthaceae, Fabaceae and Malvaceae each corresponding to $7.32 \%$ of the species. The less represented families are Cesalpiniaceae, Asteraceae, Cyperaceae, and Labieae with $2.44 \%$ of species each.

Grass species richness out of the canopy of P. reticulatum is 18 whereas it is 23 under the crown. The 23 species inventoried under the crown belongs to 14 families and the 18 species inventoried out of the crown to 11 families. Three families under the crown have not been observed out of the crown: the family of Asteraceae with Aspilia bussei O. Hoffm. Elmusch, the family of Labiaea with Englerastrum gracilium Th. C.E. Fries and the family of Polygalaceae with Polygala arenarea Willd. On the contrary, the families of Cyperaceae with Cyperus iria Linn., of Oxalidaceae with Biophyton petertianum Klotzoch in Peters are present out of the crown and absent under the crown of $P$. reticulatum. 
Table 1 presents the productive species, their specific frequencies (FSi), their centesimal frequencies (FCi) and their specific contribution (CSi). Under the crown of P. reticulatum, in the north Sudanian zone, six species are productive from which the most important are Zornia glochidiata Reighb.ex DC., and Pennisetum pedicelatum Trin., with recoveries of $54 \%$ and $45.5 \%$ and $\mathrm{CSi}$ of $25.84 \%$ and $21.77 \%$ respectively. The others productive species are: Microchloa indica Beauv., Tephrosia verticilata Bak. and Stylosanthes erecta with recoveries of $33.5 ; 14$ and $13 \%$ and $\mathrm{CSi}$ of $16.03 ; 6.69$ and $6.22 \%$ respectively. From herbaceous under the crown of $P$. reticulatum, four species are productive from which 2 have a high productivity, Microchloa indica and Zornia glochidiata with $36.69 \%$ and $31.26 \%$ of recovery and present $94.5 \%$ and $80.5 \%$ of CSi respectively. Afterward, we have Andropogon ascinodis C.B. CI and Stylosanthes erecta with recoveries of 23 and $19.5 \%$ and CSi of 8.93 and $7.57 \%$. Under the crown of P. reticulatum in south Sudanian zone, four species are the most productive, Tephrosia verticilata and Microchloa indica with recoveries of $65 \%$ and 53\% and CSi of $31.4 \%$ and $25.66 \%$ respectively. Pennisetum pedicelatum and Setaria pumula (poir.)Roem. et Schult are the species that follow with CSi of 11.62 and $10.65 \%$ and recoveries of 24 and $22 \%$ respectively. Out of the crown, Microchloa indica, Tephrosia verticilata and Setaria pumula (poïr.)Roem. et Schult. with respectively recoveries of $72 \%, 59.5 \%$ and $50.5 \%$ and CSi of $32.57 \% ; 26.92 \%, 22.85 \%$ are the most productive

Table 1. Frequencies and specific contributions of producing species according to the treatment and the site.

\begin{tabular}{|c|c|c|c|c|c|c|}
\hline Sites & Nbr of species & Producing species & F.B & $\mathrm{FSi}$ & Fci $(\%)$ & $\mathrm{Csi}(\%)$ \\
\hline & & Zornia glochidiata & Le & 108 & 54 & 25.84 \\
\hline & & Pennisetum pedicelatum & $\mathrm{Ga}$ & 91 & 45.5 & 21.77 \\
\hline & & Microchloa indica & $\mathrm{Ga}$ & 67 & 33.5 & 16.03 \\
\hline \multirow[t]{4}{*}{ SH-NS } & 23 & Stylosanthes erecta & Le & 28 & 14 & 6.69 \\
\hline & & Tephrosia verticilata & $\mathrm{Le}$ & 26 & 13 & 6.22 \\
\hline & & Microchloa indica & $\mathrm{Ga}$ & 189 & 94.5 & 36.69 \\
\hline & & Zornia glochidiata & Le & 161 & 80.5 & 31.26 \\
\hline \multirow[t]{2}{*}{ HH-NS } & 16 & Andropogon ascinodis & $\mathrm{Gv}$ & 46 & 23 & 8.93 \\
\hline & & Stylosanthes erecta & Le & 39 & 19.5 & 7.57 \\
\hline \multirow{4}{*}{ SH-SS } & & Tephrosia verticilata & Le & 130 & 65 & 31.4 \\
\hline & 23 & Microchloa indica & $\mathrm{Ga}$ & 106 & 53 & 25.66 \\
\hline & & Pennisetum pedicelatum & $\mathrm{Ga}$ & 48 & 24 & 11.62 \\
\hline & & Setaria pumula & $\mathrm{Ga}$ & 44 & 22 & 10.65 \\
\hline \multirow{3}{*}{ HH-SS } & & Microchloa indic & $\mathrm{Ga}$ & 144 & 72 & 32.57 \\
\hline & 18 & Tephrosia pedicelleta & Le & 119 & 59.5 & 26.92 \\
\hline & & Setaria pumula & $\mathrm{Ga}$ & 101 & 50.5 & 22.85 \\
\hline
\end{tabular}

FB: Biologica form; $\mathbf{F S}_{\mathbf{i}}$ : Specific frequence; $\mathbf{F C}_{\mathbf{i}}$ : Centesimal frequence; $\mathbf{C S}_{\mathbf{i}}$ : Specific contribution; $\mathbf{G a}:$ annual graminaceae; $\mathbf{G v}$ : perennial graminaceae; Le : leguminous ; SH-NS: under the crown of $P$. reticulatum in north Sudanian zone, HH-NS :out of the crown of $P$. reticulatum in the north Sudanian zone, SH-SS : under the crown of $P$. reticulatum in south Sudanian zone, HH-SS : out of the crown of $P$. reticulatum in south Sudanian zone

\subsection{Floristic Diversity}

Diversity index (Shannon-Wiener index, Simpson index and equitability index of Piélou) are presented in relation to the phytogeographical zone (Table 2).

Table 2. Floristic diversity according to the phytogeographical zone and treatment

\begin{tabular}{lllll}
\hline Area/Treatments & Number of species & H' (Shannon-Wiener) & Hmax & R (Pielou) \\
\hline SH-NS & 23 & 2.28 & 2.77 & 0.72 \\
\hline HH-NS & 16 & 1.80 & 3.17 & 0.65 \\
\hline SH-SS & 23 & 2.07 & 3.13 & 0.66 \\
\hline HH-SS & 18 & 1.73 & 2.89 & 0.60 \\
\hline
\end{tabular}

SH-NS: under the crown of $P$. reticulatum in north Sudanian zone, HH-NS : out of the crown of $P$. reticulatum in the north Sudanian zone, SH-SS : under the crown of $P$. reticulatum in south Sudanian zone, HH-SS : out of the crown of $P$. reticulatum in south Sudanian zone

Values of Shannon-Wiener index varied from 1.73 to 2.28. The index is higher under the crown of P. reticulatum compare to its value out the crown of $P$. reticulatum. 


\subsection{Structure}

The forage spectrums present large variations according to the phytogeographical area (Fig 3).

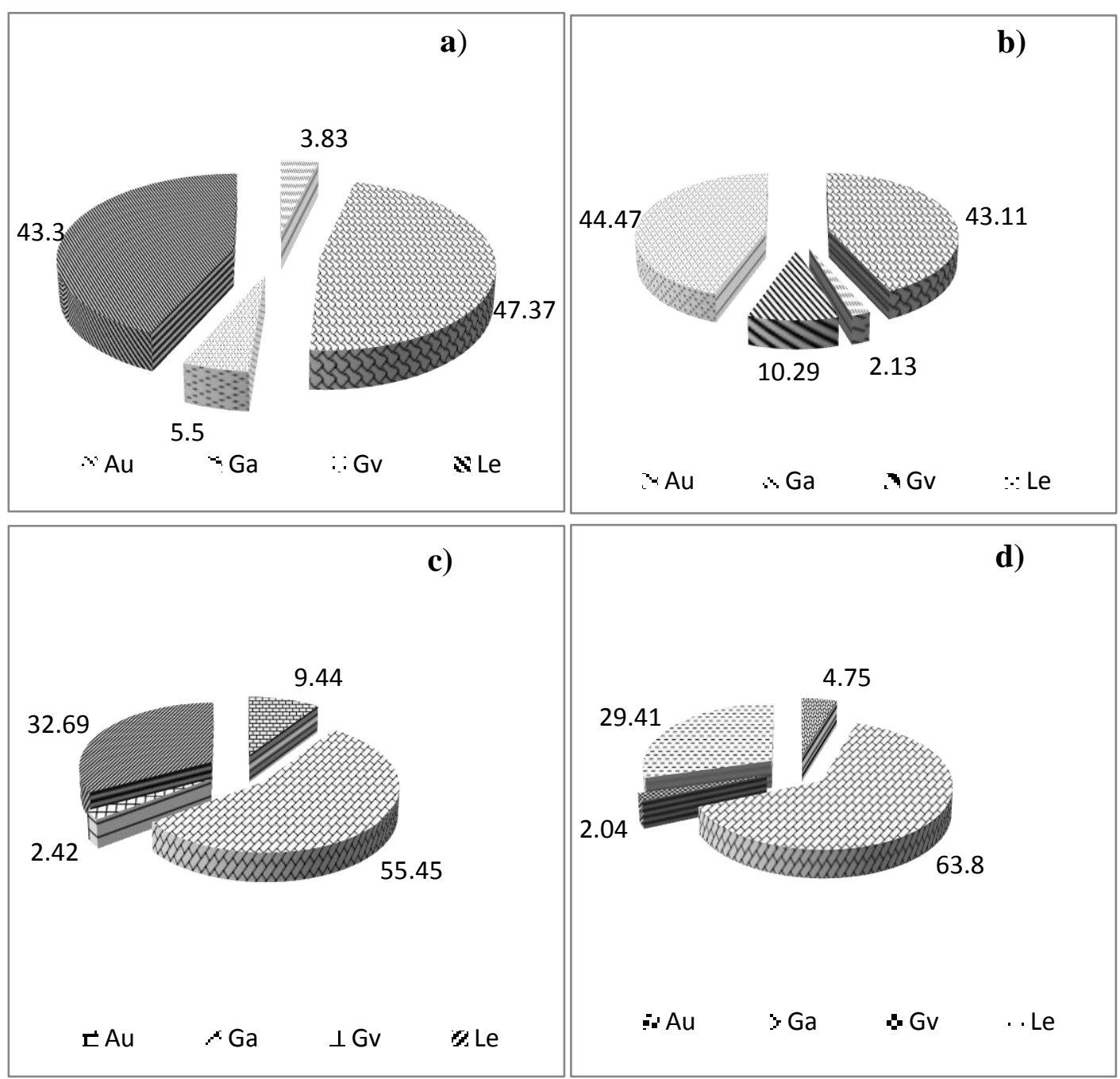

Figure 3. forage spectrums (a) under canopy and (b) out of canopy in north sudanian zone ; (c) under canopy and (d) out of canopy in south sudanian zone

In the same phytogeographical area, fodder types present low variation of CSi. Curves "J" of Raunkiaer, in the different climatic zones and independently to the treatment under and out of the crown, present variations linked to the number of species in the class of frequency 0 to $20 \%$ (Fig. 4). However, they all indicate the stability of the grass cover of $P$. reticulatum formations. 


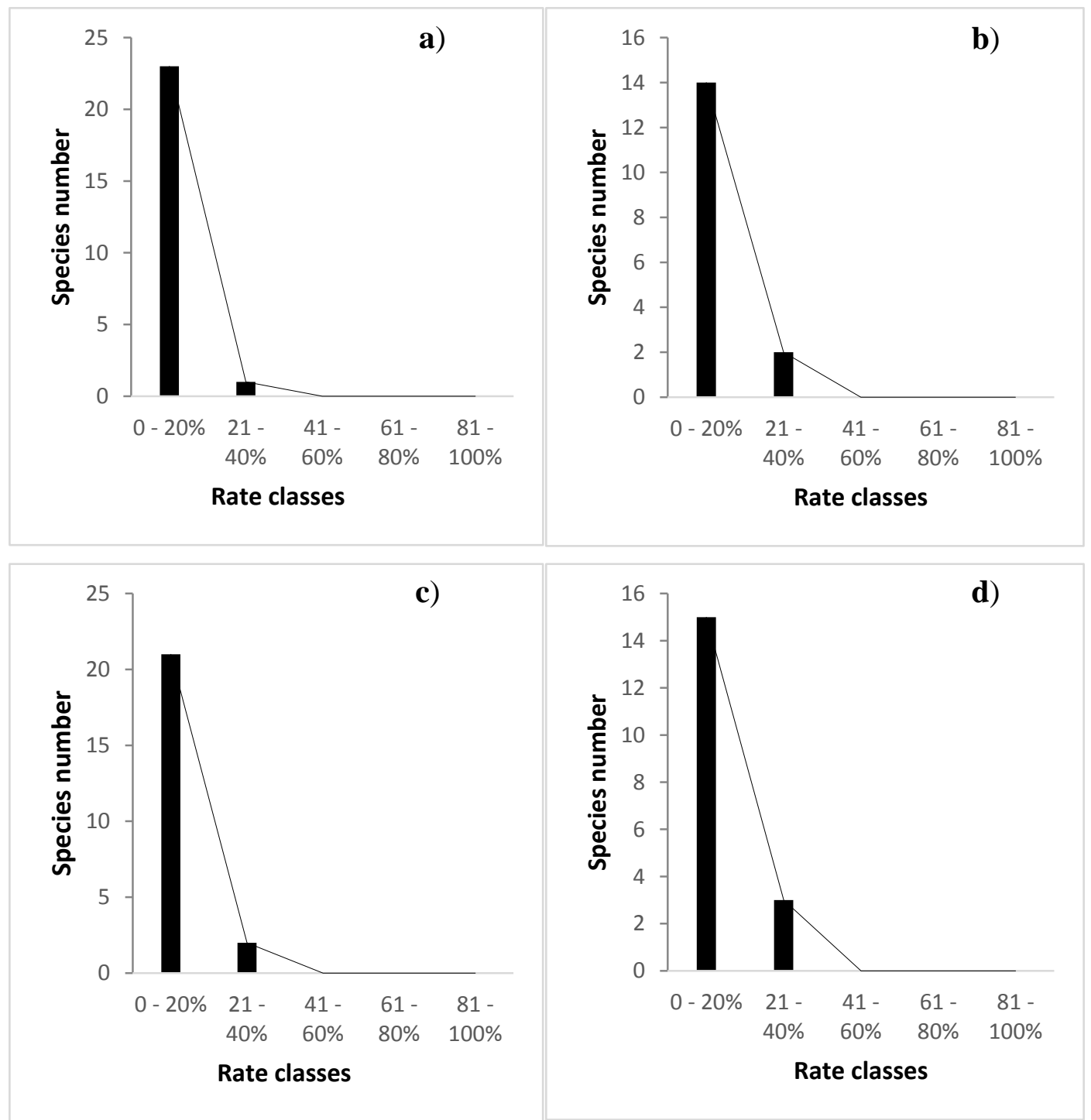

Figure 4. Raunkiaer J curve (a) under canopy and (b) out of canopy in north sudanian zone ; (c) under canopy and (d) out of canopy in south sudanian zone

The analysis of forage spectrum shows the dominance of annual graminaceae on all the two sites independently to the treatment except that out of the canopy of $P$. reticulatum at Saria where leguminous have a slight dominance. Among the 16 graminaceae recorded, 13 are annual representing $81 \%$ of the species encountered. Under the crown of $P$. reticulatum in the north Sudanian zone, a total of 23 herbaceous species have been recorded. The leguminous are the most represented ( 8 species) follow by the annual graminaceae ( 7 species). Nevertheless, annual graminaceae present the higher CSi of $47.37 \%$ compared to $43.3 \%$ for leguminous. The high CSi of Leguminous is largely due to Zornia glochidiata (with a $\mathrm{CS}_{\mathrm{i}}$ of $25.84 \%$ ), follow by Tephrosia pedicelleta and Stylosanthes erecta (6.22 and $6.70 \%$ of $\mathrm{CS}_{\mathrm{i}}$ respectively). For the annual graminaceae, the high value of CSi is due to Pennisetum pedicelatum and Microchloa indica (21.77 and $16.02 \%$ respectively). The perennial graminaceae and forbs recorded the lowest CSi with 5.5 and 3.83\% respectively. The grass layer of this biotope is stable as showed by the unimodal "J" curve of Raunkiaer.

Out of the crown of $P$. reticulatum in the north zone, five of the species recorded are annual graminaceae and five are leguminous. Afterward, forbs are the most represented with 4 species.

Only two species recorded are perennial graminaceae. Leguminous and annual graminaceae have almost the same CSi, $44.47 \%$ and $43.11 \%$ respectively. Zornia glochidita is responsible of the high contribution of leguminous whereas the high contribution of annual graminaceae is due to Microchloa indica. The flora of these areas is stable according to the unimodal "J" curve of Raunkiaer. In the south Sudanian zone, the forage 
spectrums show a clear dominance of annual graminaceae.

Under the crown of $P$. reticulatum, 8 of the 23 species inventoried are annual graminaceae. They have a CSi of $54.45 \%$ from which Microchloa indica and Pennisetum pedicelatum (25.66 and $11.62 \%$ of CSi respectively) are the most represented. Afterward, we have leguminous with species and a CSi of $32.69 \%$ mostly due to Tephrosia pedicelleta which counts alone a $\mathrm{CS}_{\mathrm{i}}$ of $31.47 \%$. The leguminous are follow by forbs which count 9 species and a CSi of $9.44 \%$ showing that a biological form can be presented by high number of species and have a low CSi. Perennial graminaceae are the lowest represented (in term of species) and have a CSi of $2.42 \%$ for 3 species.

Annual graminaceae dominate out of the crown of $P$. reticulatum with 8 species among 18 inventoried and a CSi of $63.8 \%$. This high value of CSi is due to Microchloa indica which present a CSi of 32.58\%. Annual graminaceae are followed away by the leguminous with 3 species and a CSi of 29.41\%. The perennial graminaceae are low represented with only 2 species and a CSi of $4.75 \%$. The forbs are represented by 5 species but present a low CSi $(2.04 \%)$.

\subsection{Grass Height Stratification}

The herbaceous distribution according to vertical structure shows that species having individuals with height higher than $80 \mathrm{~cm}$ are only represented under the canopy of $P$. reticulatum independently to the phytogeographic area (Fig. 5).
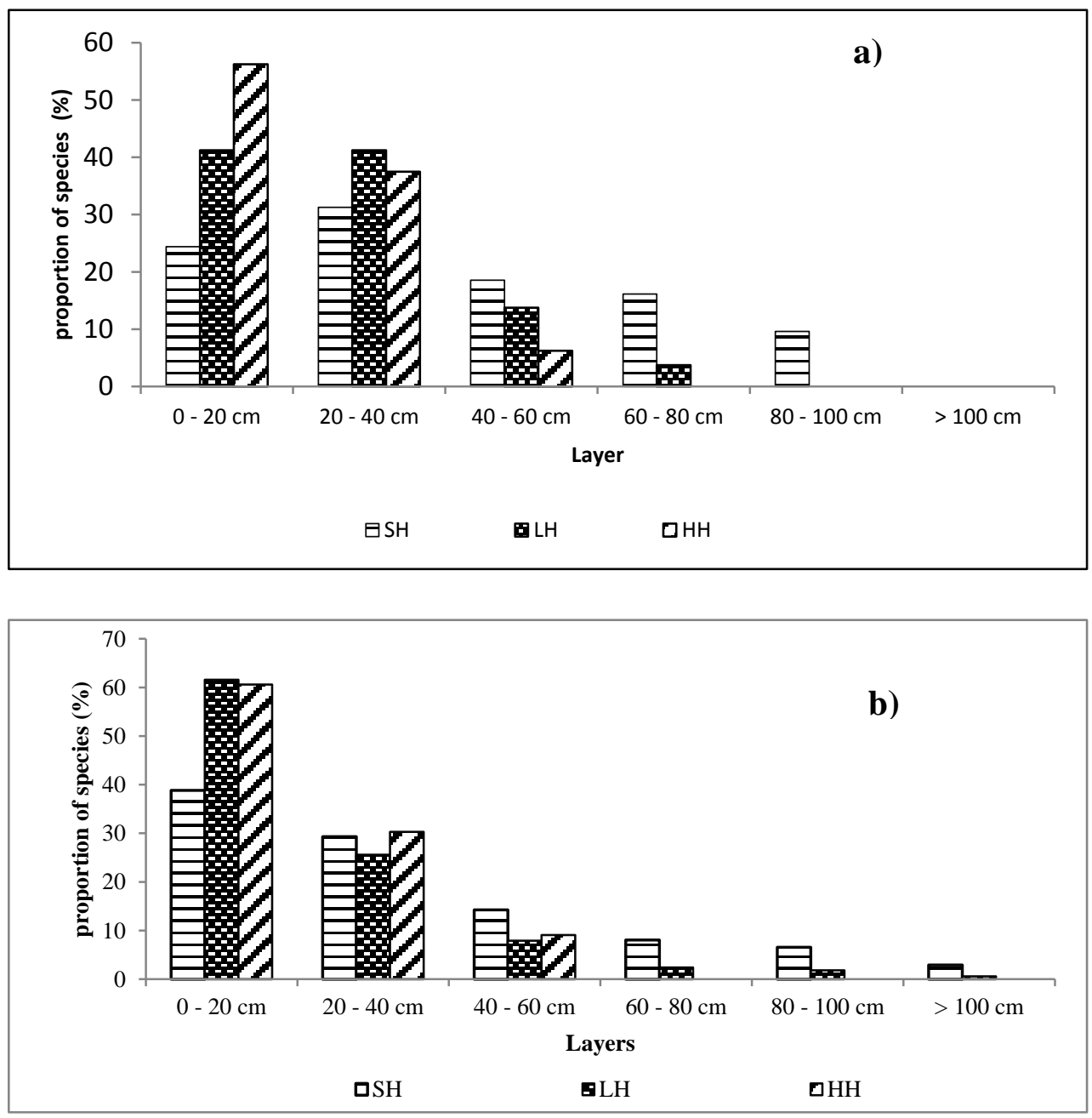

Figure 5. Distribution of herbaceous according to height classes in north (a) and south (b) Sudanian zone.

SH: under the crown of P. reticulatum, $\mathbf{L H}$ : at the limit of the crown of P. reticulatum, $\mathbf{H H}$ : out of the crown of P. reticulatum

Under the $P$. reticulatum shrub, $24.4 ; 31.27 ; 18.56 ; 16.15$ and $9.62 \%$ of the species belong to the layers $0-20$; $20-40 ; 40-60 ; 60-80$ and $80-100 \mathrm{~cm}$ respectively in the north Sudanian zone. In the plots located at the 
limit of the cover of $P$. reticulatum, the proportions of species are $41.25 ; 41.25 ; 13.75$ and $3.75 \%$ for the layers 0 $-20 ; 20-40 ; 40-60$ et $60-80$ respectively.

At open grassland, only low layers are represented: $56.25 ; 37.5$ and $6.25 \%$ of species for the layers $0-20 ; 20-$ 40; 40 - $60 \mathrm{~cm}$ respectively. No herbaceous with a higher than $60 \mathrm{~cm}$ has been observed in the control plots (out of the crown of $P$. reticulatum). Under the $P$. reticulatum shrub, the cardinal directions seem to have an effect on the herbaceous height (Table 3). The East and West directions record the higher proportions of species presenting individuals belong to the layer higher than $100 \mathrm{~cm} \mathrm{(3.13} \mathrm{and} \mathrm{4.81 \%} \mathrm{compared} \mathrm{to} 1.47$ and $1.73 \%$ for the North and the South directions respectively).

Table 3. Proportion of the different grass layer (\%) under P. reticulatum shrub in the north Sudanian zone

\begin{tabular}{lllll}
\hline $\begin{array}{c}\text { Treatments } \\
\text { Layer }\end{array}$ & P1E & P1O & P1N & P1S \\
\hline $0-20 \mathrm{~cm}$ & 26.74 & 28.36 & 20 & 22.06 \\
$20-40 \mathrm{~cm}$ & 24.42 & 20.90 & 40 & 41.18 \\
$40-60 \mathrm{~cm}$ & 20.93 & 19.40 & 17.14 & 16.18 \\
$60-80 \mathrm{~cm}$ & 17.45 & 19.40 & 14.29 & 13.23 \\
$80-100 \mathrm{~cm}$ & 10.46 & 11.94 & 8.57 & 7.35 \\
\hline
\end{tabular}

$\mathbf{P}_{1}$ E: under the $P$. reticulatum shrub, East side, $\mathbf{P}_{1} \mathbf{O}$ : under the $P$. reticulatum shrub, West side, $\mathbf{P}_{1} \mathbf{N}$ : under the $P$. reticulatum shrub, north side, $\mathbf{P}_{1} \mathbf{S}$ : under the $P$. reticulatum, south side.

In the south Sudanian zone, independently to the treatment (under and out of the cover of $P$. reticulatum), the proportion of individuals decreases from low layers to the high layers. Under the P. reticulatum shrub in the south Sudanian zone $38.83 ; 29.31 ; 14.28 ; 8.06 ; 6.59 ; 2.93 \%$ of the species have individuals belonging to the layers $0-20 ; 20-40 ; 40-60 ; 60-80 ; 80-100$ and superior to $100 \mathrm{~cm}$ respectively. The layers $60-80$ and $80-100 \mathrm{~cm}$ are not observed in the plots under the canopy of $P$. reticulatum. The herbaceous higher than $100 \mathrm{~cm}$ have only been observed in plots located under the crown of $P$. reticulatum. The cardinal direction has an effect on the height of herbaceous under the crown of $P$. reticulatum. The proportion of species having individuals reaching $100 \mathrm{~cm}$ height are 3.13 and $4.81 \%$ respectively for the East and West direction compared to 1.47 and $1.73 \%$ for the north and south directions respectively (Table 4 ).

Table 4. Proportion of different grass layers (\%) under the P. reticulatum shrub in the south Sudanian zone

\begin{tabular}{lllll}
\hline \multicolumn{1}{r}{ Treatments } & P1E & P10 & P1N & P1S \\
Layers & & & & \\
\hline $0-20 \mathrm{~cm}$ & 50 & 28.92 & 38.23 & 41.37 \\
$20-40 \mathrm{~cm}$ & 29.69 & 28.92 & 30.88 & 27.58 \\
$40-60 \mathrm{~cm}$ & 7.80 & 19.28 & 16.19 & 12.08 \\
$60-80 \mathrm{~cm}$ & 4.69 & 8.43 & 8.82 & 10.35 \\
$80-100 \mathrm{~cm}$ & 4.69 & 9.64 & 4.41 & 6.89 \\
$>100 \mathrm{~cm}$ & 3.13 & 4.81 & 1.47 & 1.73 \\
\hline
\end{tabular}

$\mathbf{P}_{\mathbf{1}}$ E: under the $P$. reticulatum shrub, East side, $\mathbf{P}_{\mathbf{1}} \mathbf{O}$ : under the $P$. reticulatum shrub, West side, $\mathbf{P}_{\mathbf{1}} \mathbf{N}$ : under the $P$. reticulatum shrub, north side, $\mathbf{P}_{1} \mathbf{S}$ : under the $P$. reticulatum, south side.

\subsection{Effect of P. reticulatum on the Production of the Herbaceous Phytomass}

In the north Sudanian zone, the evolution of herbaceous phytomass varies according to the cardinal direction (Table 5). In addition, if we consider the treatments under and out of the crown, in north Sudanian zone the production of phytomass is enhanced in $\mathrm{T}_{1} \mathrm{E}$ and $\mathrm{T}_{2} \mathrm{E}$ treatments at $524.18 \%$ and $63.39 \%$ respectively compared to their values recorded out of the crown (control). In south Sudanian zone, the evolution of the phytomass production according to the two treatments, under and out of the crown, is low. However, the trend is always the same, we have a better production under the canopy compared to the production at the limit of the crown. 
Table 5. Aboveground production $\left(\mathrm{g} / \mathrm{m}^{2}\right)$ under the shrub, at the limit and out of the cover of grass layer in the two sites

\begin{tabular}{ccc}
\hline & Aboveground biomass $\left(\mathbf{g} / \mathbf{m}^{\mathbf{2}}\right)$ \\
\hline Treatments & North Sudanian zone $^{\text {South Sudanian zone }}$ \\
\hline $\mathbf{P}_{\mathbf{1}} \mathbf{E}$ & $477.5 \pm 95.95^{\mathrm{c}}$ & $168.25 \pm 37.03^{\mathrm{ab}}$ \\
$\mathbf{P}_{\mathbf{1}} \mathbf{O}$ & $474.50 \pm 111.95^{\mathrm{c}}$ & $218.00 \pm 133.24^{\mathrm{ab}}$ \\
$\mathbf{P}_{\mathbf{1}} \mathbf{N}$ & $345.25 \pm 139.83^{\mathrm{abc}}$ & $215.75 \pm 81.50^{\mathrm{b}}$ \\
$\mathbf{P}_{\mathbf{1}} \mathbf{S}$ & $394.75 \pm 93.95^{\mathrm{ab}}$ & $229.25 \pm 70.06^{\mathrm{b}}$ \\
$\mathbf{P}_{\mathbf{2}} \mathbf{E}$ & $125.00 \pm 19.86^{\mathrm{ab}}$ & $108.50 \pm 56.44^{\mathrm{a}}$ \\
$\mathbf{P}_{\mathbf{2}} \mathbf{O}$ & $162.25 \pm 19.84^{\mathrm{ab}}$ & $151.00 \pm 37.04^{\mathrm{ab}}$ \\
$\mathbf{P}_{\mathbf{2}} \mathbf{N}$ & $161.00 \pm 37.72^{\mathrm{ab}}$ & $179.25 \pm 44.61^{\mathrm{ab}}$ \\
$\mathbf{P 2 S}^{\mathrm{ab}}$ & $132.50 \pm 37.06^{\mathrm{ab}}$ & $149.00 \pm 27.47^{\mathrm{ab}}$ \\
$\mathbf{P}_{\mathbf{3}}$ & $76.50 \pm 21.18^{\mathrm{a}}$ & $145.50 \pm 61.22^{\mathrm{ab}}$ \\
\hline $\mathbf{P}>\mathbf{F}$ & $\mathbf{0 . 0 0 2 1}$ & $<\mathbf{0 . 0 2 3}$ \\
\hline Significativity & $\mathbf{S}$ & $\mathbf{S}$ \\
\hline
\end{tabular}

In the same phytogeographical area, values with the same are not significantly different at $5 \%$ level according to Fischer test. $\mathbf{P}_{1} \mathbf{E}:$ under the $P$. reticulatum shrub, East side, $\mathbf{P}_{\mathbf{1}} \mathbf{O}$ : under the $P$. reticulatum shrub, West side, $\mathbf{P}_{\mathbf{1}} \mathbf{N}$ : under the $P$. reticulatum shrub, north side, $\mathbf{P}_{1} \mathbf{S}:$ under the $P$. reticulatum, south side, $\mathbf{P}_{2} \mathbf{E}$ : at the limit of $P$. reticulatum crown, East side, $\mathbf{P}_{2} \mathbf{O}$ : at the limit of $P$. reticulatum crown West side, $\mathbf{P}_{2} \mathbf{N}$ : at the limit of $P$. reticulatum crown north side, $\mathbf{P}_{2} \mathbf{S}$ : at the limit of $P$. reticulatum crown south side, $\mathbf{P}_{3}$ : out of the crown of $P$. reticulatum

\subsection{Effect of P. reticulatum on the Quality of Grass Phytomass}

In the north Sudanian zone, plots under the crown of $P$. reticulatum show a clear dominance of annual graminaceae. They count for 79.89; 73.87; 76.25 and $69.60 \%$ in plots $\mathrm{P}_{1} \mathrm{E}, \mathrm{P}_{1} \mathrm{O}, \mathrm{P}_{1} \mathrm{~N}$ and $\mathrm{P}_{1} \mathrm{~S}$ respectively (Fig. 6). Afterward, we have leguminous which have the largest contributions $14.27 ; 11.69 ; 17.96$ and $19.5 \%$ in plots $\mathrm{P}_{1} \mathrm{E}, \mathrm{P}_{1} \mathrm{O}, \mathrm{P}_{1} \mathrm{~N}$ and $\mathrm{P}_{1} \mathrm{~S}$ respectively. The forbs and the perennial graminaceae contribute very low to the composition of the abovegroung phytomass. In the plots located at the limit of the crown of $P$. reticulatum, the contribution of leguminous to the composition of herbaceous biomass become important. It is of 36.6; 32.35; 77.02 and $70.56 \%$ in the plots $\mathrm{P}_{2} \mathrm{E}, \mathrm{P}_{2} \mathrm{O}, \mathrm{P}_{2} \mathrm{~N}$ and $\mathrm{P}_{2} \mathrm{~S}$ respectively. So, it can be said that when we go away from the crown of $P$. reticulatum, the annual graminaceae decrease to the benefit of leguminous. This remark is confirmed in the control where $76.48 \%$ of the phytomass is constituted by leguminous.

In the south Sudanian zone, annual graminaceae have the largest contribution to total biomass independently to the treatment and the cardinal direction (Fig. 6). However, the contribution of leguminous progressively increases when we go away from the crown of $P$. reticulatum. The contribution is $16.79 ; 14.1 ; 17.56$ and $29.29 \%$ in plots P1E, P1O, P1N and $\mathrm{P}_{1} \mathrm{~S}$ respectively and reaches $33.87 \%$ in the plot $\mathrm{P}_{2} \mathrm{E}$ and $29.89 \%$ for the control. 

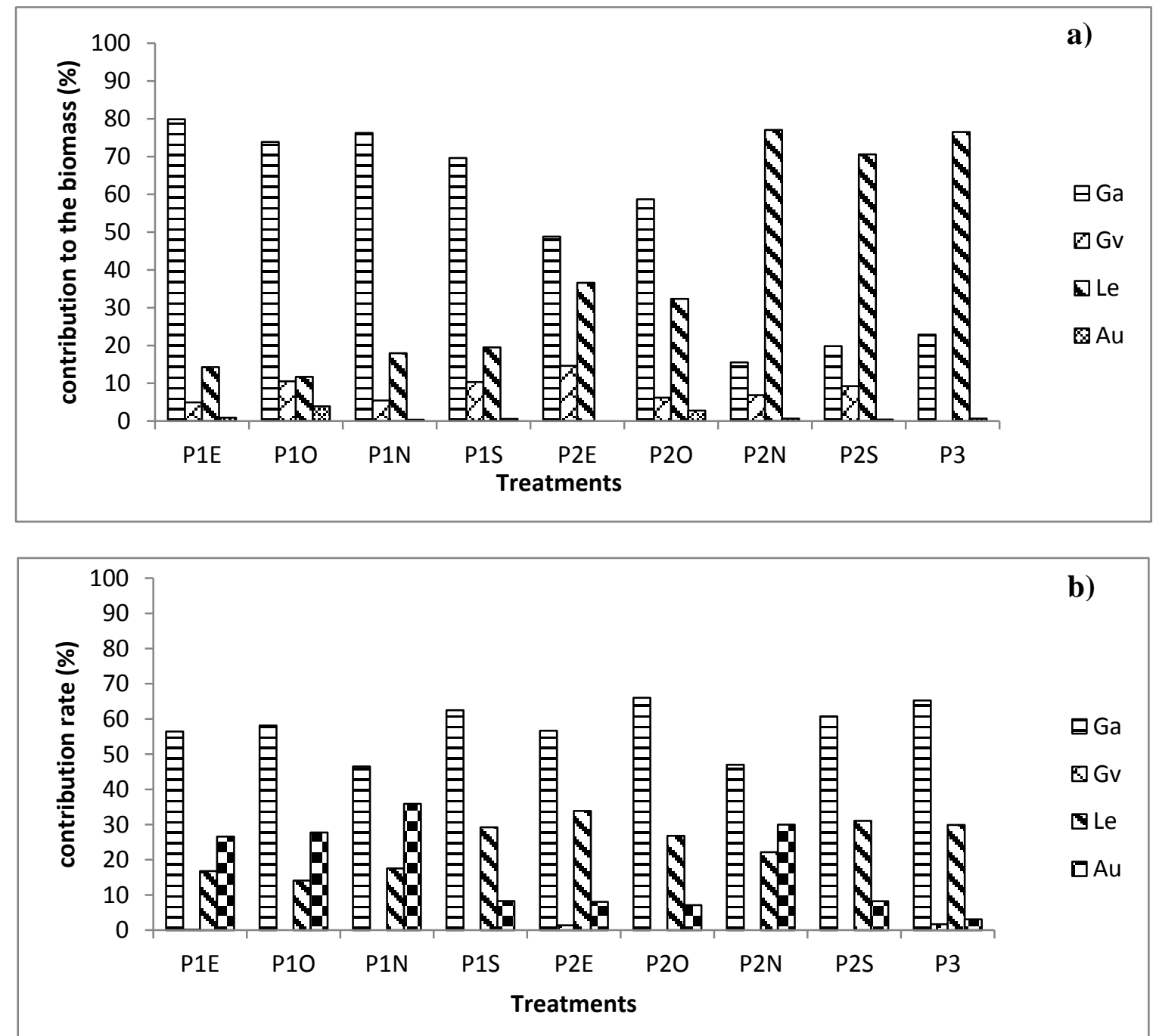

Figure 6. Contribution of forage species to vegetation biomass in the north (a) and south (b) Sudanian zone

$\mathbf{P}_{1}$ E: under the $P$. reticulatum shrub, East side, $\mathbf{P}_{1} \mathbf{O}$ : under the $P$. reticulatum shrub, West side, $\mathbf{P}_{1} \mathbf{N}$ : under the $P$. reticulatum shrub, north side, $\mathbf{P}_{1} \mathbf{S}$ : under the $P$. reticulatum, south side, $\mathbf{P}_{2} \mathbf{E}$ : at the limit of $P$. reticulatum crown, East side, $\mathbf{P}_{2} \mathbf{O}$ : at the limit of $P$. reticulatum crown West side, $\mathbf{P}_{2} \mathbf{N}$ : at the limit of $P$. reticulatum crown north side, $\mathbf{P}_{2} \mathbf{S}$ : at the limit of $P$. reticulatum crown south side, $\mathbf{P}_{3}$ : out of the crown of $P$. reticulatum, Ga: annual graminaceae; $\mathbf{G v}$ : perennial graminaceae; Le: leguminous, Au: forb

\subsection{Effect of $P$. reticulatum on the Woody Regeneration}

\subsubsection{Diversity Index}

The values of Shannon index varies from 0.69 to 1.87 (table 6). Independently to the Sudanian zone, the values of Shannon index under the cover of $P$. reticulatum are always higher compared to values recorded out of the cover (control). In the north Sudanian zone, the Shannon index is 1.3 under $P$. reticulatum shrub compared to 0.69 recorded out of the cover (control). The values are 1.71 compared to 1.27 respectively in the south Sudanian zone. The values of Piélou index vary from 1 to 0.56 . The value of Piélou index out of the cover is always higher compared to which recorded under the cover. In the north Sudanian zone, it is of 1 out of the cover and 0.81 under the cover of $P$. reticulatum. It is of 0.56 and 0.92 under the shrub and out of the cover of $P$. reticulatum respectively in the south Sudanian zone. 
Table 6. Diversity index of woody regeneration

\begin{tabular}{lllllll}
\hline Measures of diversity & SH-NS & LH- NS & HH-NS & SH-SS & LH-SS & HH-SS \\
\hline H (Shannon Wiener) & 1.3 & 0.69 & 0.69 & 1.71 & 1.87 & 1.27 \\
\hline R (Equitability of Piélou) & 0.81 & 1 & 1 & 0.56 & 0.66 & 0.92 \\
\hline
\end{tabular}

\subsubsection{State of Woody Regeneration}

In all the sites, woody species regeneration is most important under the crown of $P$. reticulatum compared to plots out of the crown (control). The most represented species in the regeneration are Guiera senegalensis J.F.Gmel., for the north Sudanian zone, Dichrostachys cinerea (L.) Wight \& Arn., Combretum glutinosum Perr. et Piliostigma reticulatum (DC.) Hochst for the south Sudanian zone.

\subsection{Structure into Diameter Classes of Woody Regeneration}

The distribution into diameter classes of young populations present an irregular trend according to the phytogeographic zone and the treatments (Fig. 7). In the north Sudanian zone, the look of the curve presents large variations between sites: reversed "J" under the crown, (L) at the limit of the crown and "J" out of the crown. Individuals with diameters higher than $15 \mathrm{~mm}$ have been only observed under the crown of $P$. reticulatum.

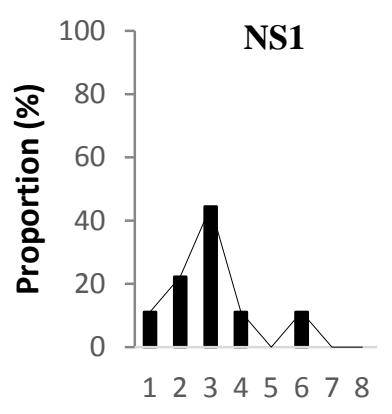

Diameter classes

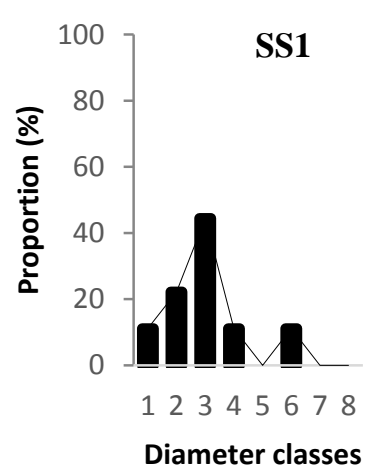

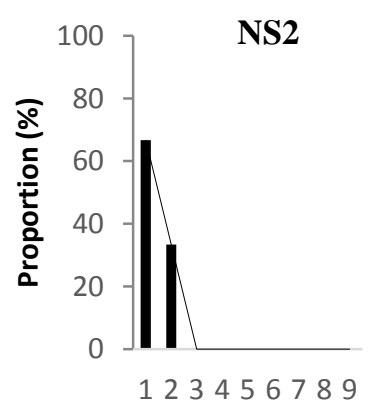

Diameter classes

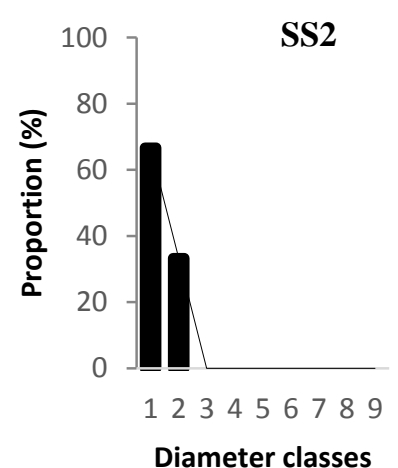

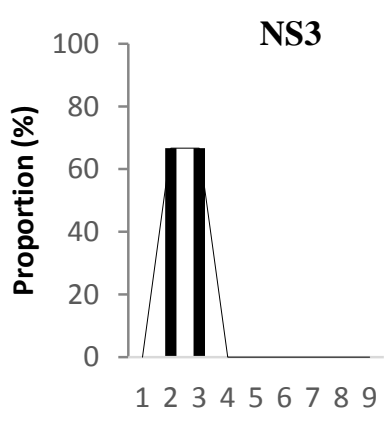

Diameter classes

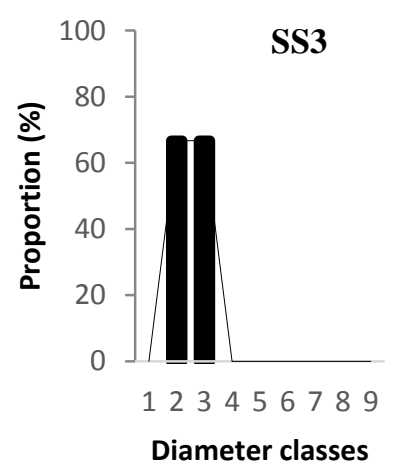

Figure 7. Collar diameter classes distribution of sapling under (1), at the limit (2) and out of the crown (3) in north and southern Sudanian zones. Diameter classes in mm: $1=[0-5[, 2=[5-10[, 3=[10-15[, 4=[15-20[, 5=$ [20-25[, $6=[25-30[, 7=[30-35[, 8=[35-40[, 9=D \geq 40$

In the south Sudanian zone, there is a variation in the curve looks according to the treatment (Fig. 7). Under the crown of $P$. reticulatum and at the limit of the crown reversed "J" curve forms have been recorded. The individuals of the class ([0-5 $\mathrm{mm}$ [) represent 57.14 to $75 \%$ of individuals under the crown of P. reticulatum and at the limit of the crown respectively. The individuals with collar diameter superior to $25 \mathrm{~mm}$ are not observed under the crown of $P$. reticulatum. In the plots out of the crown (control), no individual has more than $10 \mathrm{~mm}$ 
collar diameter.

\subsubsection{Structure into Height Classes of Woody Regeneration}

The distribution of woody regeneration into height classes allows to understand the vertical structure of young individuals. The structure into height classes of the repartition of young species varies between phytogeographical zones and between treatments (Fig. 8).

NS1

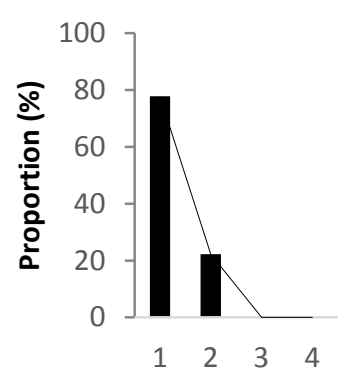

Height classes

SS1

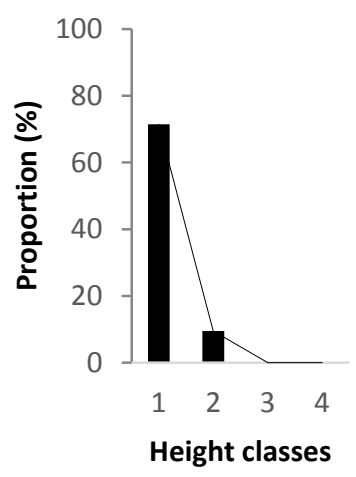

NS2

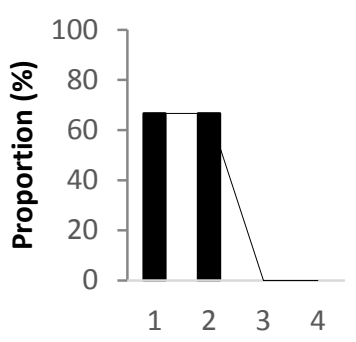

Height classes

SS2

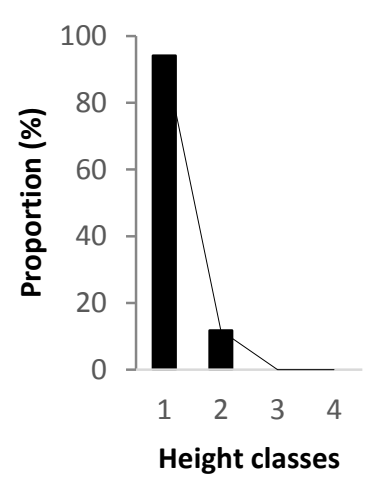

NS3

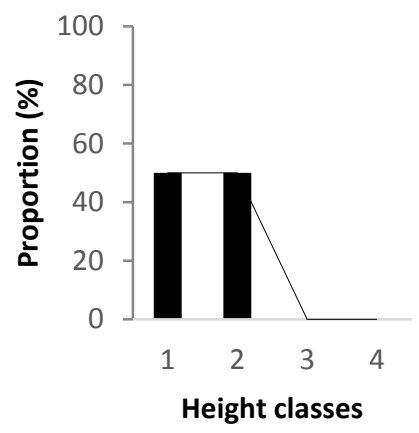

SS3

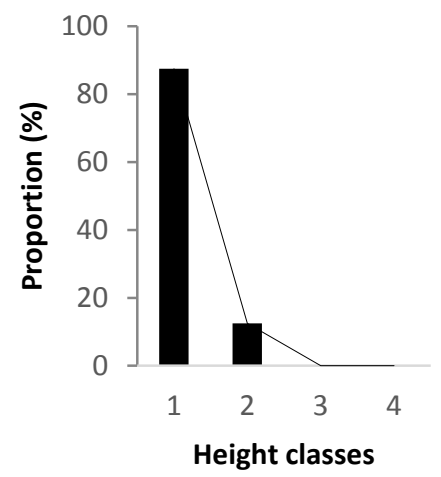

Figure 8. Vertical structure of sapling under (1), at the limit of the crown (2) and out of the crown (3) in the north and south Sudanian zones (NS and SS). Height class in cm: $1=] 0-100$ [, $2=[100-200[, 3=H \geq 200 \mathrm{~s}$

In the north Sudanian zone under the crown of $P$. reticulatum, most of the woody regeneration is represented into height class [0-1m [with $77.77 \%$ of individuals, followed by class [1-2m [ with $22.22 \%$ of individuals. No regeneration more than $2 \mathrm{~m}$ has been recorded under the crown of $P$. reticulatum nor out of the crown. It has been observed that more we go away from the crown of $P$. reticulatum, more the proportion of individuals belonging to the height class $[0-1 \mathrm{~m}$ [decreases. This proportion, that is $77.77 \%$ under the crown of $P$. reticulatum becomes $66.66 \%$ at the limit of the crown and is less than $50 \%$ in plots out of the crown (control).

In the south Sudanian zone, it is also the height class [0-1 $\mathrm{m}$ [that recorded most of the woody regeneration. Then, $71.43 \% ; 94.12 \% ; 87.5 \%$ of regeneration under the P. reticulatum shrub, at the limit of the crown and out of the crown respectively belong to $[0-1 \mathrm{~m}$ [height class. In this zone also, no sapling did not have height higher than 2 m (Fig. 8).

\section{Discussion}

\subsection{Characteristics of Grass Layer of P. reticulatum Formation}

\subsubsection{Floristic Composition}

Independently to the Sudanian zone, floristic richness is higher under the canopy of $P$. reticulatum compared to that recorded in open grassland. The floristic richness is the number of species recorded in a given area 
(Botoni/Liehoun, Daget \& César, 2006).

Each species growths on sites presenting conditions corresponding to that of its fundamental niche defined as the area of species tolerance to the main environmental factors (Fournier, 1991, Fournier, Floret \& Gnahoua, 2001). Tree canopy constitutes a favorable area to the grass layer based both on the microclimatic and soil status (Apko $\&$ Grouzis 2004, 2006). On the microclimatic basis, woody cover reduces solar radiation, air temperature and wind speed then potential evapo-transpiration (PET) is reduced. On the soil status basis, it appears that tree increases soils fertility, at less in the superficial horizon. The species characteristic of the woody cover, generally sciaphytes and hygrophytes, are in their majority, dicotyledons or monocotyledons with broad-leaves. The species characteristics of uncovered areas, generally xerophytes, mostly belong to Poaceae family with narrow leaves roughly rolled. According to Grego, Di Mattia, Moscatelli and Cacciari (2000), Alysicarpus ovalifolius, Indigofera Suffructicosa, Aspilia bussei, Englerestrum gracilium, Polygala arenarea, Biophyton petertianum are severe sciaphytes species that explains the fact that they are only observed under the crown. They have an excellent forage quality. Ours results on the herbaceous diversity under and out of the crown of $P$. reticulatum are consistent to those obtained by others authors (Apko \& Grouzi, 2004; Diallo et al. 2015) on other trees. Indeed, Apko and Grouzis (2006) found in the Senegalese Ferlo that floristic richness of herbaceous under the cover of Acacia raddiana (Savi) Brenan is significantly greater than that outside. Diallo and al., (2015) found that floristic diversity under the cover of Balanites aegyptiaca (L.) Del., Acacia tortilis subsp. raddiana (Savi) Brenan, Acacia senegal (L.) Willd, Boscia senegalensis (Pers.) Lam. ex Poir. et Sclerocarya birrea (A. Rich.) Hochst., are higher compared to that recorded outside (control). Likewise, Bationo (1994) recorded an important presence of certain herbaceous as Pennisetum pedicelatum under Guiera senegalemensis in the south center (south Sudanian zone) of Burkina Faso.

Our results show values of Piélou index changing from 0.60 to 0.72 . These values tend rather to 1 indicating an absence of predominance event. Independently to the Sudanian zone, Shannon index under the cover of $P$. reticulatum is higher compared to that outside, 2.28 compared to 1.8 and 2.07 compared to 1.73 in the north and south Sudanian zones respectively. These results indicate the existence of a gradient of herbaceous diversity from the crown of $P$. reticulatum to the open grassland: far we go away from the crown of $P$. reticulatum, more the herbaceous diversity decreases. The important floristic diversity under the crown of $P$. reticulatum has to be linked to soil richness in organic matter, total nitrogen and total phosphorus directly influenced by tree.

\subsection{Structure}

The analysis of all the "J" curves of Raunkiaer shows that $P$. reticulatum stand have a stable cover (all the curves are unimodal). Annual graminaceae are predominant on all the forage spectrums. That could be related to their ability to grow on low soil fertility (Ouédraogo, 2008). Graminaceae are species that resist to different disturbances due to their ability to develop a strategy allowing them to remain and to growth in a disturbed environment (Breman \& De Ridder, 1991). Others authors also highlighted this predominance of annual graminaceae in the vegetation of Sudanian zones (Bremann \& De Ridder, 1991; Daget \& Godron, 1995; Ouédraogo, 2008). The contribution of perennial graminacea is low on all of our inventories (5.5 and 10.29\% under and out of the crown of $P$. reticulatum respectively in the north Sudanian zone and 2.42 and $4.75 \%$ under and out of the crown of $P$. reticulatum respectively in the south Sudanian zone). This situation allows to predict a low capacity of these formations to give regrowths during the dry season especially after fires and at first rains. In north Sudanian zone (Saria) where fallow is protected (again bush fire and pasture), CSi of perennial herbaceous is higher compared to that of the south Sudanian zone (Sala). Human practices observed in the management of traditional soils negatively impact the development of herbaceous vegetation (Ouédraogo, 2008). The climatic factors, particularly low rainfall and rain distribution along the year, low relative humidity during a long period of the year and biotic factors (low degradation of organic matter) are all defavorable conditions to the growth of perennial herbaceous species (Ousseina, Ricardo, Fortina, Marichatou \& Yenikoye, 2013). We have to highlight that man negative actions is more perceptible on the degradation of the vegetation compared to climatic factors. This low contribution of perennial graminaceae in the herbaceous cover in Sudanian zone has been mentioned by Ouédraogo, (2008).

Considering especially Microchloa indica species, we found that independently to the Sudanian zone, its CSi is higher out of the crown of $P$. reticulatum compared to the value recorded under the crown. In the north Sudanian zone, we have recorded a CSi of 16.03 and $36.69 \%$ under and out of the crown of P. reticulatum respectively. Referring to the five successive steps in the evolution of a savanna subjected to pasture (Botoni/Liehoun et al., 2006), it appears that the apparition of the small annual graminaceae Microchloa indica corresponds to the fifth step. This step is characterized by the degradation of the plant cover. It is an ultimate step that forecasts the total denudation of the soil. The crown of $P$. reticulatum, reducing the CSi of Microchloa indica, constitutes an 
important actor of fighting soil denudation then enhancing pasture.

\subsection{Influence of P. reticulatum on the Production of Grass Phytomass}

The annual production of grass layer is always higher under the cover compared to outside independently to the experimental site. For several arid and semi-arids regions, similar results have been reported (Weltzin \& Coughenou, 1990; Apko \& Grouzis, 2004, 2006). In return, these results are not consistent to those recorded in sub humid zones where it has been reported that the woody cover has depressive effect on herbaceous production compared to the production in open grassland (Akpo et al., 2003). The effect of the tree on the production is more favorable in ecological zone with low rainfall compared to zones with great rainfall and where woody density is higher (Akpo \& Grouzis, 2004; Apko et al 2003). This explains that in north Sudanian zone the difference in herbaceous production between the cover of $P$. reticulatum and production in outside is largest compared to the difference in south Sudanian zone. Analyzing several works achieved in Africa under different bioclimats (from $150 \mathrm{~mm}$ to $1200 \mathrm{~mm}$ of annual rainfall), Akpo \& Grouzis (2000) sets the rainfall threshold $(100-800 \mathrm{~mm})$ and the threshold of woody recovery $(60 \%)$ at which the effect of tree is null. However, our results didn't sustain this threshold sets by Akpo \& Grouzis (2000) because the rainfall in our sites is higher than $800 \mathrm{~mm}$ though the benefit of tree on the herbaceous production is effective. The morphology of the crown of $P$. reticulatum could explain our results.

\subsection{Effect of P. reticulatum on Woody Regeneration}

Our results show a low diversity of woody regeneration of $P$. reticulatum formations. However, independently to the Sudanian zone, the diversity index of woody regeneration are always higher under the canopy of $P$. reticulatum compared to outside. Others authors highlighted the beneficial effect of tree on woody regeneration. Akpo \& Grouzis (2000) showed that tree enhances the regeneration of certain woody species: plots under canopy presenting a regeneration higher more than 7 times compared to the regeneration outside the canopy. Akpo \& Grouzis, (2004) found higher lifting under Acacia raddiana, Balanites aegyptiaca and Ziziphus mauritiana.

The large woody regeneration under the crown compared to the regeneration outside could be explain by the fact that the crown constitutes a preferential area for ruminants rest and a better perch for birds then allows the dissemination (Akpo \& Grouzis 2004).

\section{Conclusion}

In the Sudanian conditions, $P$. reticulatum enhances herbaceous diversity and production, and woody regeneration under its crown compared to the open grassland. In south Sudanian zone, except CSi of perennial herbaceous, the floristic diversity (woody and herbaceous), the height of herbaceous is higher compared to north Sudanian zone. The study undertaken on the influence of $P$. reticulatum on the functioning of grass layer and woody regeneration showed a benefit effect of tree in the Sudanian zone. The floristic diversity (Woody and herbaceous) and the production of herbaceous biomass are greater under the canopy of $P$. reticulatum. Based on the results obtained during this experimentation, P. reticulatum is recommanded in tree plantation processes aiming to enhance biodiversity and the herbaceous production in transhumance zones. This recommendation is all the more valuable that the clove of $P$. reticulatum is consumed by cattle.

\section{References}

Akpo, L. E., Banoin, M., \& Grouzis, M., (2003). Effet de l'arbre sur la production et la qualité fourragères de la végétation herbacée : bilan pastoral en milieu sahélien. Revue Méd. Vét., 154(10), 619-628.

Akpo L. E., \& Grouzis, M. (2000). Valeur pastorale des herbages en région soudanienne, le cas des parcours sahéliens du Nord-Sénégal. Tropicultura, pp. 1-8.

Akpo L. E., \& Grouzis M. (2004). Interactions arbre/herbe en bioclimat semi-aride : influence de la pâture. Sécheresse, 15(3), 253-61

Akpo L. E., \& Grouzis, M. (2006). Interactions arbre-herbe au Sahel. Sécheresse, 17(1-2), 318-25.

Akpo L. E., \& Grouzis, M. (2009). Effet des arbres sur la diversité de la végétation herbacée dans les parcours communautaires du Nord - Sénégal (Afrique de l'Ouest), 272-293.

Bationo B. A. (1994). Etude des potentialités agroforestières, de la multiplication et des usages de Guierra senegalensis. Mémoire IDR Ouagadougou, 70 pages

Botoni/Liehoun, E., Daget, P., \& César, J. (2006). Activités de pâturage, biodiversité et végétation pastorale dans la zone Ouest du Burkina Faso. Revue Élev. Méd. vét. Pays trop, 59(1-4), 31-38.

https://doi.org/10.19182/remvt.9951 
Boudet, G. (1984). Manuel sur les Pâturages Tropicaux et les Cultures Fourragères (4e éd, révisée). IEMVT : Maisons-Alfort, 266.

Breman, H., \& De Ridder, N. (1991). Manuel sur les pâturages des pays sahéliens. CTAACCT-Karthala, Paris, 486p.

Daget, P., \& Godron, M. (1995). Pastoralisme: Troupeaux, espaces et sociétés. HATIER, AUPELF, UREF, Universités francophones, $510 \mathrm{p}$.

Daget, P., \& Poissonet, J. (1971). Un procédé d'estimation valeur pastorale des pâturages. Fourrages, 31-39.

Diallo, M., Ndiaye, O., Diallo, A., Saleh, M., Bassene, C., Wood, S. A., Diop, A., \& Guisse, A. (2015). Influence de la litière foliaire de cinq espèces végétales tropicales sur la diversité floristique des herbacées dans la zone du Ferlo (Sénégal). Int. J. Biol. Chem. Sci. 9(2), 803-814. https://doi.org/10.4314/ijbcs.v9i2.20

Fournier, A. (1991). Phénologie, croissance et production végétales dans quelques savanes d'Afrique de l'ouest. Variation selon un gradient climatique. Thèse de Doctorat d'État, université Pierre et Marie Curie (Paris VI), $312 \mathrm{p}$.

Fournier, A., Floret, C., \& Gnahoua, G. M. (2001). Végétation des jachères et succession post-culturale en Afrique tropicale. John Libbey Eurotext, 123-168.

Godron, M., Daget, P., Emberger, L., Long, G., Le, floc'h, E., Poissonet, J., Sauvage, Ch., \& Wacquant, J. M. (1969). Vade-mecum pour le relevé méthodique de la végétation et du milieu. C.N.R.S. Paris, $170 \mathrm{p}$.

Grego, S., Di, Mattia, E., Moscatelli, M. C., Cacciari, I. (2000). Functional Diversity Of Microbial communities present in the rhizosphere of Acacia tortilis: an ecophysiological approach. In Floret Ch., Pontanier R., éd.: La jachère en Afrique tropicale, Paris, John Libbey Eurotext: 300-307.

Ouédraogo, D. (2008). Caractérisation des ressources fourragères et des pratiques pastorales du terroir de Kotchari à la périphérie du parc w. Mémoire d'ingénieur UPB/IDR, 87 p + annexes.

Ouédraogo, N. M. (2003). Influence de différentes herbacées sur les indicateurs chimiques et biologiques de la fertilité des sols. Mémoire de fin d'études d'Ingénieur du développement Rural (IDR), Université Polytechnique de Bobo Dioulasso, Bobo Dioulasso (Burkina Faso).

Ousseina, S., Riccardo, Fortina, R., Marichatou, H., \& Yenikoye, A. (2013). Dynamique du peuplement herbacé de la station sahélienne expérimentale de Toukounous (Filingué - Niger). Int. J. Biol. Chem. Sci. 7(2), 657-671. https://doi.org/10.4314/ijbcs.v7i2.22

Savadogo, P. (2007). Dynamics of sudanian savanna woodland ecosystem in response to disturbances. PhD thesis. Swedish university of agricultural sciences, (Sweden).

Sawadogo, L. (1996). Evaluation des potentialités pastorales d'une forêt classée nord soudanienne au Burkina Faso (cas de la forêt classée de Tiogo). Université de Ouagadougou /FAST, Ouagadougou (Burkina Faso).

Sawadogo, L. (2009). Influence de facteurs anthropiques sur la dynamique de la végétation des forêts classées de Laba et de Tiogo en zone soudanienne du Burkina Faso. Thèse Doctorat d'Etat, Université de Ouagadougou, Ouagadougou (Burkina Faso).

Yelemou, B., Yameogo, G., Bationo, B. A., Millogo/Rasolodimby, J., \& Hien, V. (2008). Biologie florale et mode de reproduction sexuée de Piliostigma reticulatum, (DC) Hochst., Int. J. Biol. Chem. Sci., 2(3), 281-291

Yélemou, B., Bationo, B. A., Yaméogo, G., \& Millogo-Rasolodimby, J. (2007). Gestion traditionnelle et usage de Piliostigma reticulatum (D.C.) Hochst., dans le plateau central du Burkina Faso. Bois et For. Trop., 291, 55-65. http://bft.cirad.fr/cd/BFT_291_55-66.pdf

Weltzin, J. F., Coughenou, MU, B., (1990). Savanna tree influence on understory vegetation and soilnutrients in northwestern Kenya. J. Veget. Sci., 1, 325-334. https://doi.org/10.2307/3235707

\section{Copyrights}

Copyright for this article is retained by the author(s), with first publication rights granted to the journal.

This is an open-access article distributed under the terms and conditions of the Creative Commons Attribution license (http://creativecommons.org/licenses/by/4.0/). 